\title{
KONTRADIKTIF PENERAPAN HUKUM PAJAK BERGANDA DI INDONESIA
}

\author{
H a t t a \\ Mahasiswa Program Doktor Ilmu Hukum Pascasarajana UMI Makassar \\ hatta_rola@yahoo.co.id
}

\begin{abstract}
This study focused on the policy aspects of the law, especially in the field of tax law. In addition, this study examines and assesses the policy process tax law in determining the double taxation prevention methods which tend to emphasize the comparison method Bilateral and Multilateral Unilateral methods. This research was conducted using the method of normative basing on primary legal materials. The results showed that, emphasizes the aspects of bilateral methods of avoiding double taxation can only regulate the avoidance of double taxation for foreign taxpayers alone, but to set the avoidance of double taxation in the country more appropriate use of unilateral methods. For the method of multilateral results are less than the maximum because there are different interests of countries that enter into agreements.
\end{abstract}

Keywords : Multiple Taxes; Methods Prevention; Tax Treaty;

\begin{abstract}
Abstrak
Penelitian ini difokuskan pada aspek kebijakan hukum, terutama di bidang hukum perpajakan. Selain itu, penelitian ini mengkaji dan menilai proses kebijakan undang-undang perpajakan dalam menentukan metode pencegahan perpajakan berganda yang cenderung menekankan metode perbandingan metode Bilateral dan Multilateral Unilateral. Penelitian ini dilakukan dengan menggunakan metode normatif mendasarkan pada bahan hukum primer. Hasil penelitian menunjukkan bahwa, menekankan aspek metode bilateral menghindari pajak berganda hanya dapat mengatur penghindaran pajak berganda untuk wajib pajak asing saja, tetapi untuk mengatur penghindaran pajak berganda di negara tersebut lebih tepat menggunakan metode unilateral. Untuk metode hasil multilateral kurang maksimal karena ada berbagai kepentingan negara yang masuk ke dalam perjanjian.
\end{abstract}

Kata kunci: Pajak Berganda; Metode Pencegahan; Perjanjian pajak;

\section{A. PENDAHULUAN}

Pelaksanaan pembangunan di Negara kesatuan Republik Indonesia dimaksudkan untuk mempercepat proses pencapaian tujuan Negara sebagaimana tertuang dalam pembukaan Undang-Undang Dasar 1945, terwujudnya masyarakat adil dan makmur. Dalam rangka mencapai pelaksanaan pembangunan sebagai salah satu tujuan Negara,

Vol. 20 No. 1 Mei 2018 
maka dibutuhkan sejumlah dana terutama dana yang dialokasikan dalam anggaran pendapatan dan belanja pada setiap Negara.

Salah satu sumber penerimaan Negara yang paling besar adalah sektor penerimaan pajak, dimana pajak merupakan salah satu instrumen vital dari sumber pendapatan Negara. Tanpa pajak, negara tidak akan mampu membiayainprogram-program pembangunan dan operasional pemerintahan. Tidak hanya Negara Indonesia saja pajak menjadi sumber penerimaan Negara, akan tetapi Negara lain juga memperioritaskan pajak sebagai sumber penerimaan Negara yang paling sentral. Hal ini terlihat seperti pada falsafah hukum Negara Inggris yang berbunyi "No Taxation Without Representation", serta di Amerika Serikat berbunyi "Taxation Without Representation is Robbery".

Bercermin pada Negara maju seperti Amerika Serikat dan Inggris, Negara indnesia juga mempunyai falsafah pemungutan pajak yang berbunyi "segala pajak untuk keperluan Negara diatur dengan undang-undang". ${ }^{1}$ Pemungutan pajak atas undang- undang merupakan suatu kelaziman suatu Negara hukum (recht staat), sehingga pemungutan pajak tersebut tidak bernada rapasan atau perampokan hak milik.

Masalah pajak pada saat ini tidak hanya menjadi permasalahan satu Negara saja, melainkan terjadi disetiap Negara-negara tertentu dalam hal anggaran pendapatan dan belanja Negara, sehingga pemungutan pajak merupakan kewenangan mutlak suatu Negara dan Negara yang bersangkutan berhak untuk menentukan syarat dan azas-azas yang akan dipergunakan sebagai dasar dalam menyatakan keadilannya untuk memungut pajak kepada warga Negaranya.

Seiring dengan meluasnya hubungan internasional mempunyai aspek beraneka ragam, baik dari aspek ekonomi, moneter mapun hukum, termasuk didalamnya aspek hukum pajak. Dari aspek hukum pajak, Setiap Negara mempunyi yuridisdiksi hukum pajak sendiri dan setiap Negara menganut azas pemungutan yang saling berlainan yang lazim menimbulkan konflik hukum yang satu dengan yang lainnya. ${ }^{2}$ Meskipun masalah pemungutan pajak merupakan kewenangan mutlak suatu Negara, namun sering menimbulkan pertautan internasional dalam hal perpajakan sebagi segi internasional dari hukum pajak. Sehingga titik pertalian antara dua Negara atau lebih dalam hal pemungutan pajak tersebut mengenai subyek dan obyek pajaknya dapat menimbulkan ketegangan antara dua Negara, bila masing-masing Negara tetap berpegang pada pendiriannya bahwa negaranyalah yang lebih berkompeten yang memungut maupun mengenakan pajak terhadap subyek pajak tertentu.

Selain dapat menimbulkan ketegangan antara dua Negara juga dapat menimbulkan pajak ganda. Timbulnya pajak ganda merupakan salah satu masalah perpajakan yang bersegi internasional. Hal ini akan sangat memberatkan bagi wajib pajak (Tax Payer), bahkan azas umum dan merata terhadap pemungutan pajak bisa saja ditinggalkan. Selain itu juga dapat menimbulkan dampak antara lain: a) Memberikan tambahan beban ekonomi terhadap pengusaha, b) Menjadi resiko terkena pemajakan berganda terhadap perluasan usaha ke mancanegara, c) Memicu ekonomi global dengan biaya tinggi serta menghambat mobilitas global.

Penghindaran pajak berganda harus dihindari karena dapat menimbulkan keriguian

\footnotetext{
${ }^{1}$ Undang-Undang Dasar 1945 Pasal 23

${ }^{2}$ Rachmat Sumitro. 1982. Hukum Pajak dan Pembangunan. Eresco: Bandung. h. 166
} 
dari berbagai pihak baik subje maupun objek pajak. Dalam rangka penghindaran pajak berganda tersebut, maka dibutuhkan metode dan model yang tepat dalam menghindari pajak ganda.

\section{B. ANALISIS DAN PEMBAHASAN}

\section{Pajak Ganda}

Pajak pada dasarnya merupakan bantuan, baik secara langsung maupun tidak yang dipaksakan oleh kekuasaan publik dari penduduk atau dari barang, untuk menutup belanja pemerintah (Beaulieu : 1906). Oleh karenanya pajak merupakan kewajiban semua warga masyarakat dan hukum pajak mengatur hubungan antara penguasa/ Negara dengan warganya baik orang atau badan dalam pemenuhan kewajiban perpajakan kepada Negara. ${ }^{3}$ Hal ini sejalan dengan pasal 23A Amandemen Undang-Undang Dasar 1945 yang menegaskan bahwa pajak dan pungutan lainnya yang bersifat memaksa untuk keperluan Negara diatur dengan undang-undang. Dengan demikian pajak secara yuridis tergolong dalam hukum public yaitu hukum administrasi atau tata usaha Negara. Proses pemajakan merupakan bagian dari proses administrasi perpajakan. Sebagaimana diketahui istilah administrasi pajak dipandang sebagai penatausahaan dan pelayanan atas hak-hak dan kewajiban-kewajiban pembayar pajak, dan bisa diartikan sebagai sebuah system, fungsi dan lembaga. ${ }^{4}$

Beranjak dari pandangan ini terlihat bahwa pemungutan pajak merupakan serangkaian proses administrasi yang bertujuan untuk memperoleh uang pajak berlandaskan undang-undang perpajakan yang mengaturnya. ${ }^{5}$ Perkembangan yang terjadi saat ini menunjukkan peningkatan hubungan antarmasyarakat bangsa dari berbagai penjuru Negara dimana Negara tersebut menanamkan modalnya di Indonesia maupun sebaliknya sejumlah perusahaan Indonesia yang menerbitkan obligasinya di Negara lain. ${ }^{6}$ Hal semacam ini menimbulkan ketegangan antara dua Negara atau lebih yang menimbulkan adanya pajak ganda internasional. Selain itu pajak ganda juga ditimbulkan karena perbedaan peraturan hukum dan penjelasan yang berlainan dari peraturan hukum.

Pajak Ganda dapat diartikan sebagai setiap bentuk pembebanan pajak dan pungutan lainnya lebih dari satu kali, baik dalam bentuk berganda maupun lebih pada suatu fakta fiskal sesuai dengan negara (yuridiksi) pemungut pajaknya, dan dapat dikelompokkan menjadi pajak berganda internal atau domestik dan pajak berganda international (Knechtle : 1979). Sedangkan pajak ganda internasional dapat diartikan sebagai pengenaan jenis pajak yang sama oleh dua negara atau lebih terhadap subjek pajak dan atas objek pajak yang sama, serta dalam periode yang identik (pajak ganda international yuridis). Dapat

\footnotetext{
${ }^{3}$ Anshari Ritonga. 2007. Pembaharuan Perpajakan dan Hukum Fiskal Formal Indonesia. Yayasan Bina Baca Aksara. Jakarta. h.19

${ }^{4}$ Gunadi. 2004. Reformasi Aministrasi Perpajakan dalam Rangka Kontribusi Menuju Good Governance. Pidato Pengukuhan sebagai Guru Besar Ilmu Perpajakan Fakultas Ilmu Sosial dan Ilmu Politik. UI. Jakarta.

${ }^{5}$ Wirawan B Ilyas. Kontradiksi Sanksi Pidana dalam Hukum Pajak. Jurnal Hukum. IV. 18 Oktober 2011. h.525-542

${ }^{6}$ Seperti seseorang yang berkewarganegaraan Indonesia yang berdomisili di Malaysia yang memiliki perusahaan di Singapura. Demikian juga halnya kasus yang terjadi pada sejumlah perusahaan Indonesia yang menerbitkan obligasi di Belanda yang terancam tidak lagi mendapatkan keringanan pajak.
}

Vol. 20 No. 1 Mei 2018 
pula diartikan sebagai pengenaan jenis pajak yang sama oleh dua negara (atau lebih) terhadap subjek pajak yang berlainan atas objek pajak yang sama (pajak ganda internasional ekonomis). Dalam pasal 23 A dan 23 B model Persetujuan Penghindaran Pajak Berganda OEC membedakan pajak berganda yuridis (juridica double taxation) dengan pajak ganda ekonomis (economical double taxation) yaitu Pajak berganda yuridis terjadi apabila atas penghasilan yang sama yang diterima oleh orang yang sama dikenakan pajak oleh lebih dari satu negara sedangkan pajak berganda ekonomis terjadi apabila dua orang yang berbeda (secara hukum) dikenakan pajak atas suatu penghasilan yang sama (atau identik).

Dari uraian ini dapat diketahui bahwa pajak ganda disebabkan adanya perbedaan dalam stelsel pajaknya, yaitu bentrokan antara pajak-pajak subyektif dengan pajak obyektif, dan jika stelselnya sama, maka masih dapat timbul pajak ganda dalam hal terdapat defenisi yang berlainan tentang pengertian tertentu. ${ }^{7}$ Artinya timbulnya pajak ganda pada dasarnya muncul karena subyek yang sama dan obyek yang sama.

Obyek yang sama dimaksudkan, timbulnya pajak yang dikenakan pada pajak yang sama di beberapa Negara dikarenakan adanya domisili yang rangkap dimasing-masing Negara dimana kedua Negara tersebut menganut azas domisili dalam mengenakan pajak. Sebagai contohnya, wajib pajak X berada di Negara A, berada 16 bulan di Negara B, jika menurut peraturan di Negara A bahwa wajib pajak yang meninggalkan Negara A tidak lebih dari 18 bulan masih dianggap sebagai wajib pajak di Negara A tersebut, sedangkan bagi Negara B menganggap bahwa lebih dari 12 bulan berada dinegaranya sudah dianggap sebagai wajib pajak di Negara B. Dengan demikian wajib pajak X tersebut secara bersama-sama dianggap sebagai penduduk domisili di Negara A dan dinegara B sehingga akan dikenakan pajak baik untuk Negara A maupun untuk Negara B.

Selain azas domisili, azas kebangsaan juga menjadi factor penyebab timbulnya pajak ganda, apalagi terjadinya bentrokan antara azas domisili dengan azas kebangsaan. Seperti contoh kasus wajib pajak X yang karena bertempat tinggal di Negara A yang menganut azas domisili, dikenakan pajak oleh Negara A untuk seluruh penghasilannya yang diperoleh dimana saja, sedangkan di Negara B yang menganut azas kebangsaan atau kewarganegaraan juga dikenakan pajak untuk seluruh penghasilannya karena wajib pajak $\mathrm{X}$ adalah warga Negara dari Negara $\mathrm{B}$.

Selain subjek yang sama, objek pajak yang sama bisa menimbulkan pajak ganda. Obyek yang sama juga meruapakan bagian dari pendapatan yang diperoleh atau transaksi yang dilakukan di Negara lain dikarenakan pajak yang sama pada lebih dari satu Negara. Misalnya, wajib pajak X yang bertempat tinggal di Negara A melakukan usaha di Negara $\mathrm{B}$ dengan suatu permanent estabilishment dan dengan perantaraan pendirian tetap itu memberikan jasa-jasa dibidang teknologi dan pengetahuan kepada relasinya C. Dalam hubungan ini Negara C dapat mengenakan pajak terhadap X karena

${ }^{7}$ Rahmat Soemitro. Bahan Kuliah Hukum Pajak Internasional, Sub Konsorsium Ilmu Hukum. Direktorat Perguruan Tinggi Departemen Pendidikan dan Kebudayaan. h. 39

Vol. 20 No. 1 Mei 2018 
Negaranya tempat melakukan jasa-jasa tersebut, sedangkan Negara B dapat mengenakan pajak karena pendirian tetap itu di Negara B.

Selain adanya bentrokan antara azas domisili dan azas kebangsaan, bentrokan antara azas domisili dengan azas sumber juga bisa menimbulkan pajak ganda. Sumber yang sama dikenakan pajak dinegara tempat tinggal berdasarkan pendapatan yang diperolehnya sedangkan di Negara tempat dimana badan pengusaha terletak dikenakan pajak berdasarkan azas sumber karena mempunyai pendapatan yang berasal dari suatu sumber di Negara itu. Sebagai contoh, wajib pajak X yang bertempat tinggal di Negara A melakukan perusahaan di Negara B dengan suatu pendirian tetap Negara A, jika menganut azas domisili akan menyamakan pajak kepada X, sedangkan Negara B yang menganut azas sumber mengenakan pajak atas hasil yang diperoleh dari sumber yang ada di Negara itu.

\section{Metode Pencegahan Pajak Ganda}

Secara ekonomis pajak merupakan pengorbanan sumberdaya (kemampuan ekonomis) yang harus ditanggung oleh pengusaha dan masyarakat. Pajak berganda sebagai akibat dari pemajakan oleh dua ketentuan pemajakan dari dua negara, sehingga berdampak pada a) Memberikan tambahan beban ekonomi terhadap pengusaha. b) Dengan adanya perluasan usaha ke mancanegara akan mengudang risiko terkena pemajakan berganda. c) Memicu ekonomi global dengan biaya tinggi dan menghambat mobilitas global sumberdaya ekonomis.

Menilik dari permasalahn yang mendasar ini, maka dibutuhkan adanya kebijakan dan metode yang tepat dalam menghadapi damapak dan resiko pajak berganda baik nasional maupun internasional.

Secara umum dikatakan bahwa terjadinya pajak ganda merupakan suatu persoalan yang memberatkan setiap wajib pajak, baik wajib pajak orang atau wajib pajak badan. Ada beberapa cara untuk menghilangkan atau mencegah pajak ganda dapat ditempuh dengan berbagai cara, yaitu melalui metode Unilateral, Bilaateral dan Multilateral.

Secara Unilateral pajak dimaksudkan bahwa Negara yang bersangkutan memasukkan secara sepihak dalam perundang-undangan pajak nasionalnya terhadap suatu ketentuan-ketentuan untuk mencegah terjadinya pajak ganda, dengan menggunakan prinsip-prinsip hukum pajak internasional yang sudah diterima baik oleh Negara. ${ }^{8} \mathrm{Di}$ Indonesia cara untuk mencegah terjadinya pajak ganda terlihat dalam beberapa peraturan perpajakannya yakni ordonantie untuk mencegah terjadinya pajak ganda terdapat dalam Statblad tahun 1934 nomor 291 terakhir dirubah dengan Staatblad 1949 nomor 174. Ordinatie tersebut mengatur tentang pencegahan pajak ganda untuk pajak pendapatan, dan ketentuan tersebut berlaku bagi setiap orang yang memenuhi syarat-syarat.

Secara Bilateral atau secara perjanjian fiscal dimaksudkan menghindari pajak ganda dengan mengadakan traktat atau perjanjian fiscal dengan Negara lain, baik secara

\footnotetext{
${ }^{8}$ Bohari. 2004. Pengantar Hukum Pajak. Jakarta : PT. Raja Grapindo Persada. h. 28
} 
bilateral maupun multilateral. Indonesia sejak kemerdekaan, baru untuk pertama kalinya mengadakan perjanjian perpajakan yaitu dengan Negara Belanda yang sudah ditanda tangani pada tanggal 5 Maret 1973.

\section{Tax Treaty}

Salah satu cara yang ditawarkan oleh Indonesia dalam menghindari pajak ganda adalah dengan mengadakan persetujuan pengindaran pajak ganda dengan dengan Negara lain. Metode yang ditempuh oleh Negara Indonesia dalam persetujuan Penghindaran Pajak Berganda (P3B) atau tax treaty ${ }^{9}$ adalah melalui metode bilateral dengan menggunakan acuan model OECD untuk Negara maju, United Nations untuk Negara berkembang dan United State untuk Amerika. Persetujuan Penghindaran Pajak Berganda memiliki struktur tertentu yang mencakup 27-30 pasal, dengan setiap pasal memberikan definisi atau batasan tentang ketentuan perpajakan yang disepakati kedua Negara. ${ }^{10}$

Pada Persetujuan Penghindaran Pajak Berganda penjelasannya terdiri dari; Pasal 1 menjelaskan tentang Personal Scope yaitu kepada siapa Persetujuan Penghindaran Pajak Berganda tersebut berlaku. Pasal 2 diatur tentang taxes covered yaitu jenis pajak yang ketentuan perpajakan antar dua Negara diatur dengan Persetujuan Penghindaran Pajak Berganda tersebut. Misalnya dalam Persetujuan Indonesia-Malaysia, untuk Indonesia mencakup Pajak Penghasilan (PPh), sedangkan untuk Malaysia mencakup income tax dan excess profit tax, supplementary income tax dan petroleum income tax. Dan mulai Pasal 6 dan seterusnya dalam persetujuan penghindaran pajak berganda diatur ketentuan perpajakan terhadap berbagai jenis penghasilan, misalnya penghasilan dari immovable property, business profit atau capital gain.

Pajak berganda pada dasarnya tidak bisa dihindari jika masing-masing Negara memiliki azas pemungutan pajak yang berbeda, ${ }^{11}$ akan tetapi pajak berganda itu bisa di uraikan pada bentuk perjanjian kesepakatan yang bersifat diplomatik antara kedua Negara atau lebih sehingga pajak berganda bisa menurunkan beban dari wajib pajak dalam membayar pajaknya.

Indonesia sendiri dalam hal menghindari pajak ganda menggunakan metode bilateral dengan model OECD bagi Negara maju seperti Eropa Barat dan Amerika Utara, model UN bagi Negara berkembang dan model US untuk Negara Amerika. Dengan berlakunya tax treaty maka dalam suatu Negara terdapat dua sumber hukum dalam perpajakan terhadap wajib pajak, khususnya wajib pajak yang berasal dari Negara treaty

9 Tax Treaty merupakan traktat atau perjanjian yang dilakukan oleh dua Negara atau lebih yang menyangkut tentang perpajakan merupakan sumber hukum pajak internasional

${ }^{10}$ Direktorat Jendral Pajak Kementerian Keuangan Republik Indoensia

11 Sebagaimana terlihat pada azas pemungutan pajak yaitu a) Azas domisili yaitu pajak dikenakan terhadap worldwide income milik subyek pajak yang berdomosili atau berlokasi di suatu Negara. b) Azas sumber yaitu pajak dikenakan terhadap income yang bersumber dari suatu Negara tanpa melihat subyek pajak dalam negeri (SPDN) atau subyek pajak luar negeri (SPLN). c) Azas kewarganegaraan yaitu pengenaan pajak berdasarkan status kewarganegaraan dimana seorang warga Negara wajib membayar pajak kapada negaranya, dimanapun yang bersangkutan tinggal dan dari manapun incomenya diperoleh.

Vol. 20 No. 1 Mei 2018 
partner. Yang paling mendasar dalam hal ini adalah ketentuan dalam tax treaty dan yang kedua adalah ketentuan dalam undang-undang perpajakan domestic.

Sehubungan dengan hal ini, yang perlu dipertimbangkan adalah tax treaty memberikan wewenang pemajakan. Jika wewenang pemajakan telah diberikan kepada salah satu Negara perjanji, maka ketentuan dalam undang-undang perpajakan domestic yang seterusnya akan berlaku. Misalnya seorang akuntan dari Singapura mendapatkan job kerja di Indonesia dalam hal ini di Jakarta. akuntan tersebut berada dijakarta dalam rangka melakukan kegiatan professional selama 93 hari, maka berdasarkan Pasal 13 Persetujuan Penghindaran Pajak Berganda Indonesia-Singapura, ${ }^{12}$ yang berwenang mengenakan pajak atas penghasilan yang diterima atau diperoleh akuntan tersebut di Indonesia adakah fiskus Indonesia. Jadi hak pemajakannya ada pada fiskus Indonesia. Selanjutnya apakah akuntan tersebut akan dianggap sebagai Wajib Pajak Dalam Negeri atau Wajib Pajak Luar Negeri, maka ketentuan Undang-Undang Pajak Penghasilan di Indonesia yang berlaku. Karena dalam UU PPh 2000 time test-nya untuk menentukan apakah termasuk Wajib Pajak Dalam Negeri atau Wajib Pajak Luar Negeri adalah lebih dari 183 hari dalam jangka waktu dua belas bulan, maka akuntan tersebut diklasifikasikan sebagai Wajib Pajak Luar Negeri. Penghasilannya di Indonesia dikenakan PPh Pasal 26, yakni dengan tarif PPh sebesar 20\% atas gross basis.

Persetujuan Penghindaran Pajak Berganda atau tax treaty lebih superior daripada undang-undang domestik. Dalam hal terjadi benturan antara tax treaty dan undangundang domestik, maka yang superior adalah ketentuan dalam tax treaty. Misalnya dalam Pasal 26 UU PPh disebutkan, bahwa atas pembayaran dividen ke luar negeri terutang PPh Pasal 26 sebesar 20\% dari bruto. Sedangkan dalam Pasal 10 tax treaty tarifnya adalah $10 \%$. Maka yang berlaku adalah tarif dalam tax treaty yakni yang $10 \%$.

Selain itu Tax treaty tidak menciptakan pajak baru. Jika dalam pasal-pasal dalam tax treaty tercantum jenis pajak lain di luar yang telah mempunyai dasar hukum dalam bentuk undang-undang di Indonesia, maka pajak tersebut tidak berlaku bagi Indonesia. Jenis pajak itu hanya berlaku bagi negara mitra penjanji saja. Dalam hal ini dapat dijadikan contoh ketentuan yang diatur dalam Pasal 2 UN Model tentang Tax Covered, yang berisi tentang pajak-pajak yang diliputi oleh perjanjian perpajakan yang disepakai oleh kedua belah pihak. Pasal 2 ayat 2 UN Model menyebutkan, bahwa: "there sehall be regarded as taxes on income and on capital all taxes imposes on total income . . as well as taxes on capital appreciation".

Tax on capital appreciation adalah pajak penghasilan yang dikenakan terhadap kenaikan nilai modal atau harta. Misalnya jika pada awal tahun WP A membeli valas sebesar USS5000 dengan kurs @ Rp.8.000,- dan pada akhir tahun kurs telah menjadi @ Rp.9.500,-- dengan kasat mata dapat diketahui bahwa nilai kurs telah naik @ Rp.1.500,-Jika dijual di pasar uang WP A akan menerima laba kurs 5.000 x Rp.1.500,- = Rp.7.500.000,-- Apakah terhadap laba kurs tersebut akan menjadi Objek Pajak Penghasilan di Indonesia? Untuk menjawab hal ini perlu diketahui sistem pajak penghasilan yang di anut di Indonesia sehubungan dengan capital appreciation tersebut.

\footnotetext{
12 Dinyatakan bahwa time test melebihi 90 hari dalam jangka waktu dua belas bulan
} 
Sistem pajak penghasilan di Indonesia menganut asas realization principle, artinya penghasilan baru akan dikenakan pajak apabila penghasilan telah direalisasi, baik secara cash basis maupu secara accrual basis. Dengan demikain jika valas sebesar US\$5000 tersebut masih tetap ada dalam lemari besi WP A, artinya belum dijual ke pasar uang, maka laba kurs tersebut belum dapat dikenakan pajak. Tapi, jika misalnya valas tersebut dijual ke pasar uang, maka laba kurs tersebut sudah dapat dikenakan pajak.

Dengan demikian capital appreciation yang diatur dalam Pasal 2 UN Model tersebut tidak berlaku bagi penduduk Indonesia, dan hanya berlaku bagi penduduk pada Negara mitra penjanji. Jadi tax tax treaty tidak menciptakan pajak baru selain dari yang telah diatur undang-undang.

\section{PENUTUP}

Kebutuhan akan dana yang demikian besar untuk pembangunan Negara Indonesia selayaknya memerlukan sudut pandang yang jelas akan penerapan metode dan kebijakan perpajakan di masa mendatang sebagai landasan hukum pemungtan pajak. Metode perpajakan sebagai bagian dari metode dalam meningkatkan penerimaan Negara baik secara hukum maupun secara administrasi haruslah dipandang sebagai metode yang bersifat universal yang tidak boleh dibelokkan kearah kepemihakan terhadap orang atau badan tertentu. Kemauan dari petugas pajak untuk memahami keadaan demikian perlu dikoordinasikan dengan baik. Dengan demikian aspek kebijakan dalam penghindaran pajak berganda baik nasional maupun internasional perlu dikaji ulang agar tidak menjadi kontradiktif di dalam penerapannya sehari-hari. Jadi, penerapan metode dan kebijakan yang menguntungkan masyarakat Indonesia dan kesejahteraannyalah yang perlu didahulukan agar tujuan mensejahterakan dan memberikan keadilan bagi seluruh rakyat Indonesia bisa segera direalisasikan sebagaimana tercantum di dalamm pembukaan UUD 1945.

Melihat dari teori tentang kebijakan dan metode dalam penghindaran pajak ganda untuk kesejahteraan Indonesia terdapat tiga metode, yaitu Metode unilateral yang mana metode ini ternyata masih memiliki pelbagai kebaikan yang banyak dibandingkan kelemahan yang dikandungnya. Keuntungan dengan menggunakan metode unilateral dalam menghindari pajak berganda adalah pembuatan ketentuannya yang relative lebih mudah karena tidak perlu melibatkan atau tergantung kepada Negara lain. Disamping itu, penerapannya pun mudah karena sepenuhnya berdasarkan ketentuan-ketentuan UndangUndang Nasional. Kerugiannya, terdapat aspek-aspek pajak ganda internasional yang tidak dapat dipecahkan secara sepihak (unilateral). Misalnya, pajak ganda yang timbul sebagai akibat adanya kependudukan rangkap (dual residence) tidak dapat dipecahkan secara unilateral karena menyangkut kepentingan dan system serta hukum pajak Negara lain. Di samping itu, ketentuan penghindaran pajak ganda unilateral umumnya hanya mengatur penghindaran pajak untuk wajib pajak dalam negeri (resident tax payer) tidak mengatur penghindaran pajak untuk wajib pajak luar negeri (non- resident taxpayer).

Vol. 20 No. 1 Mei 2018 


\section{DAFTAR PUSTAKA}

Anshari Ritonga. 2007. Pembaharuan Perpajakan dan Hukum Fiskal Formal Indonesia. Yayasan Bina Baca Aksara. Jakarta.

Aristanti Widyaningsih. 2011. Hukum Pajak dan Perpajakan. Bandung: Alfabeta.

Bohari. 2004. Pengantar Hukum Pajak. Jakarta : PT. Raja Grapindo Persada.

Diana Sari. 2013. Konsep Dasar Perpajakan. Bandung: Refika Aditama.

Direktorat Jendral Pajak Kementerian Keuangan Republik Indoensia

Gunadi. 2004. Reformasi Aministrasi Perpajakan dalam Rangka Kontribusi Menuju Good Governance. Pidato Pengukuhan sebagai Guru Besar Ilmu Perpajakan Fakultas Ilmu Sosial dan Ilmu Politik. UI. Jakarta.

Jaja Zakaria. 2005. Perlakuan Perpajakan Terhadap Bentuk Usaha Tetap (BUT). Jakarta: PT. Raja Grafindo Persada.

Husen, L. O. 2009. Hukum Pajak dan Hak Privilege. CV. Utomo, Bandung

Husen, L. O., Sampara, S., \& Qamar, N. Salle. 2017. Iktisar Filsafat Ilmu: Dalam Perspektif Barat dan Islam.

Rachmat Sumitro. 1982. Hukum Pajak dan Pembangunan. Eresco: Bandung.

Nawi, R. 2015. Pengaruh Kebijakan Publik terhadap Kualitas Pelayanan, penguatan Kelembagaan dan Kinerja Organisasi Pemerintahan. Pleno Jure, 4(5), 42-55.

. Bahan Kuliah Hukum Pajak Internasional, Sub Konsorsium Ilmu Hukum. Direktorat Perguruan Tinggi Departemen Pendidikan dan Kebudayaan.

Soerjono Soekarno dan Sri Mamudji. 1986. Penelitian Hukum Normatif, Suatu Tinjauan Singkat, cetakan kedua, Jakarta : CV.Rajawali.

Wirawan B Ilyas. Kontradiksi Sanksi Pidana dalam Hukum Pajak. Jurnal Hukum. IV. 18 Oktober 2011. 